\title{
JENIS DAN MODEL JARING LABA-LABA (Araneae) DI WILAYAH KELURAHAN SAMATA KECAMATAN SOMBA OPU KABUPATEN GOWA
}

\author{
Hasyimuddin $^{1}$, Syahribulan $^{2}$, Nurlaela ${ }^{1}$ \\ ${ }^{1}$ Jurusan Biologi UIN Alauddin Makassar \\ ${ }^{2}$ Departemen BiologiUniversitas Hasanuddin Makassar \\ Email: hasyimuddin@uin-Alauddin.ac.id
}

\begin{abstract}
Abstrak: Laba-laba merupakan organisme yang tergolong dalam filum Arthropoda, kelas Arachnida dan ordo Araneae. Laba-laba dikenal ada dua jenis yaitu laba-laba pemburu (tidak memiliki jaring) dan laba-laba jaring yang membutuhkan jaring untuk menagkap mangsanya. Tujuan penelitian ini adalah untuk mengetahui jenis dan model jaring laba-laba yang berada di wilayah kelurahan Samata Kecamatan Somba Opu Kabupaten Gowa. Pengamatan laba-laba dilakukan dengan metode jelajah dengan mengamati sudut sudut rumah, pekarangan, tumpukan barang bekas, pot-pot bunga dan tempat-tempat yang dianggap sebagai habitat laba-laba. Hasil penelitian terdapat 11 spesies laba-laba jaring yang tergolong ke dalam 6 Famili yang ditemukan di wilayah kelurahan Samata Kecapatan somba Opu Kabupaten Gowa. Spesies yang ditemukan adalah Steatoda bivunctata, Wulfila saltabundus, Cryptachaea porter, Parasteatoda tepidariorum, Enoplognatha ovate, Pholcus phalangoides, Nephila clavipes, Nephila inaurata, Araneus diadematus, Philodromus sp, Argiope argentata. Model jaring yang ditemukan umumnya berbetuk bulat melingkar
\end{abstract}

Kata Kunci: Ragam Jenis, Laba-laba Jaring, Model Jaring

\section{PENDAHULUAN}

I aba-laba merupakan organisme yang tergolong dalam filum Arthropoda, kelas Arachnida dan ordo Araneae. Terdapat sekitar 43.678 spesies laba-laba yang tergolong dalam 111 famili dan 3.600 genus yang telah berhasil diidentifikasi hingga saat ini (Koneri, 2016). Laba-laba dikenal ada dua jenis yaitu laba-laba pemburu (tidak memiliki jaring) dan laba-laba jaring yang membutuhkan jaring untuk menagkap mangsanya (Suana, 2005). Asriani dkk, 2010 mendapatkan 11 jenis laba-laba dari 6 famili yang di peroleh dari kecamatan Duampanua Kabupaten Pinrang.

Laba-laba merupakan kelompok organisme yang memiliki peran penting dalam sebuah ekosistem. Organisme ini berperan sebagai pemangsa insekta sehingga bisa menjadi pengendali populasi serangga hama (Koneri dan Saroyo, 2015). Laba-laba memiliki fungsi dan peran dalam ekosistem namun informasi terkait taksonomi dan ekologinya di Indonesia masih terbatas (Lia, 2017).

Penelitian ini bertujuan untuk mengetahui jenis dan model jaring laba-laba yang berada di wilayah kelurahan Samata Kecamatan Somba Opu Kabupaten Gowa. 


\section{METODE PENELITIAN}

Penelitian ini dilaksanakan pada bulan September sampai Oktober 2017 di daerah perumahan warga kelurahan samata yang dibagi dalam 4 stasiun sesuai arah mata angin.

Pengamatan laba-laba dilakukan dengan metode jelajah dengan mengamati sudut sudut rumah, pekarangan, tumpukan barang bekas, pot-pot bunga dan tempat-tempat yang dianggap sebagai habitat laba-laba.

Sampel laba-laba diambil menggukan pinset kemudian dimasukkan kedalam botol yang berisi alkohol $70 \%$ untuk selanjutnya diidentifikasi di Laboratorium. Pengamatan model jaring laba-laba dilakukan pada saat pengamatan dan dilakukan pemotretan untuk mendapatkan data model jaring laba-laba.

\section{HASIL DAN PEMBAHASAN}

Dari penelitian yang telah dilakukan di wilayah kelurahan samata didapatkan 11 spesies laba-laba yang termasuk ke dalam 6 Famili. Jenis-jenis laba-laba yang didapatkan disajikan pada Tabel 1.

Tabel 1. Jenis Laba-laba (Araneae) Di wilayah Kelurahan Samata Kecamatan Somba Opu Kabupaten Gowa

\begin{tabular}{|c|c|c|c|c|c|c|}
\hline \multirow{2}{*}{ No } & \multirow{2}{*}{ Famili } & \multirow{2}{*}{ Genus / Spesies } & \multicolumn{4}{|c|}{ Stasiun } \\
\hline & & & 1 & 2 & 3 & 4 \\
\hline 1 & \multirow{5}{*}{ Theridiidae } & Steatoda bivunctata & - & - & $\sqrt{ }$ & - \\
\hline 2 & & Wulfila saltabundus & - & $\sqrt{ }$ & - & - \\
\hline 3 & & Cryptachaea porteri & - & $\sqrt{ }$ & - & - \\
\hline 4 & & Parasteatoda tepidariorum & - & - & $\sqrt{ }$ & - \\
\hline 5 & & Enoplognatha ovata & - & - & - & $\sqrt{ }$ \\
\hline 6 & Pholcidae & Pholcus phalangoides & $\sqrt{ }$ & $\sqrt{ }$ & $\sqrt{ }$ & $\sqrt{ }$ \\
\hline 7 & \multirow{2}{*}{ Nephilidae } & Nephila clavipes & - & - & - & $\sqrt{ }$ \\
\hline 8 & & Nephila inaurata & - & - & - & $\sqrt{ }$ \\
\hline 9 & Entelegynae & raneus diadematus & - & $\sqrt{ }$ & - & - \\
\hline 10 & Philodromidae & Philodromus sp & $\sqrt{ }$ & - & - & - \\
\hline 11 & Arneidae & Argiope argentata & $\sqrt{ }$ & - & - & $\sqrt{ }$ \\
\hline
\end{tabular}

Dari tabel 1 dapat dilihat terdapat 6 famili yang terdapat pada wilayah kelurahan Samata. Dari ke enam Famili tersebut, Famili Theridiidae memiliki jumlah spesies terbanyak yaitu 5 spesies. Famili Nephilidae terdapat 2 spesies sedangkan Famili Pholcidae, Entelegynae, Philodromidae dan Arneidae masing masing hanya memiliki 1 spesies. Menurut (Gagit, Dkk, 2016) Famili Theridiidae merupakan salah satu laba laba pembuat jaring yang hidup diberbagai habitat dan banyak ditemukan di daerah tropis.

Kehadiran Laba-laba pada suatu ekosistem sangat dipengaruhi oleh faktor lingkungan seperti suhu, angin, kelembaban dan intensitas cahaya. Sedangkan faktor yang membatasi kehadiran laba-laba dalam sebuah ekosistem adalah ketersediaan makanan, tipe vegetasi, pesaing dan musuh musuhnya (Koneri dan Saroyo, 2015).

Famili Theridiidae ditemukan di ranting pohon dengan kondisi yang terang dan di sudut sudut rumah. Famili ini merupakan predator serangga kecil seperti nyamuk dan lalat. Spesies dari family Nephilidae ditemukan di ranting pohon dengan intensitas cahaya yang redup. Famili ini merupakan predator bagi serangga kecil seperti capung, kupu-kupu, kumbang dan serangga kecil lainnya yang terperangkap pada jaringnya. 
Pholcus phalangoides didapatkan pada setiap stasiun pengamatan. Habitat spesies ini berada di tumpukan kayu bekas kandang, di sudut ruangan dengan kondisi yang gelap. Spesies ini merupakan predador bagi lalat dan nyamuk dan bahkan dapat memangsa laba-laba jenis lain.

Spesies Araneus diadematus dari family Aranedae ditemukan di ranting-ranting pohon. Spesies ini memiliki ciri khas dengan punggung abdomen berwarna kuning dan pada bagian ventral terdapat tanda melingkar berwarna kuning.

Berdasarkan model jaring, didapatkan 10 model jaring yang umumnya berbetuk bulat melingkar. Adapun bentuk model jaring disajikan pada tabel 2.

Tabel 2. Model jaring Laba-laba (Araneae) pada wilayah Kelurahan Samata

\begin{tabular}{cll}
\hline No & \multicolumn{1}{c}{ Spesies } & \multicolumn{1}{c}{ Model Jaring } \\
\hline 1 & Steatoda bivunctata & Heksagonal melingkar \\
\hline 2 & Wulfila saltabundus & Bulat melingkar seperti bunga \\
\hline 3 & Cryptachaea porteri & Bulat meruncing \\
\hline 4 & Parasteatoda tepidariorum & Bulat melingkar berdempetan \\
\hline 5 & Enoplognatha ovata & Menyambung tidak beraturan \\
\hline 6 & Pholcus phalangoides & Berbentuk bintang dan gumpalan asap \\
\hline 7 & Nephila clavipes & Bulat melingkar berjarak \\
\hline 8 & Nephila inaurata & Bulat melingkar berjarak \\
\hline 9 & Araneus diadematus & Heksagonal tidak rapat \\
\hline 10 & Philodromus sp & Garis lurus dengan pintalan benang melingkar \\
\hline 11 & Argiope argentata & Berbentuk huruf X \\
\hline
\end{tabular}

Dari tabel 2 dapat dilihat laba-laba memiliki jaring yang berbeda beda sesuai dengan jenis laba-labanya. Umumnya model jaring yang ditemukan berbentuk bulat melingkar dengan ujung jaring masing-masing ditempatkan pada dinding bangunan atau ranting pohon. Barrior dan Litsinger (1995) mengemukakan bahwa laba-laba membuat sarang dengan tipe membulat dan menunggu mangsanya di tengah-tengah jaring. Laba laba jaring sangat erat kaitannya dengan arsitektur vegetasi dan bangunan karena merupakan prasyarat untuk menempatkan jaringnya (Maramis, 2014).

Model jaring Argiope argentata yang merupakan anggota Famili Araneidae memiliki model jaring berbentuk huruf X dimana jaring-jaringnya dilekatkan pada cabang-cabang pohon kecil yang ternaung. Laba-laba dari kelompok Araneidae memerlukan tajuk yang luas untuk meletakkan konstruksi jaringnya untuk menagkap mangsa (Maramis, 2014). Menurut (Gagit, Dkk, 2016) Laba laba anggota Araneidae ditemukan pada vegetasi pohon yang memiliki cahaya yang minim karena laba laba tersebut merupakan predator nocturnal. Suana dan Haryono (2013) melaporkan Neoscoma nautica salah satu anggota family araneidae aktif memangsa pada rentang waktu pukul 18.00-21.00 dan kembali meningkat pada pukul 03.00-06.00

\section{KESIMPULAN}

Kesimpulan dari penelitian ini adalah terdapat 11 spesies laba-laba jaring yang tergolong ke dalam 6 Famili yang ditemukan di wilayah kelurahan Samata Kecapatan somba Opu Kabupaten Gowa. Spesies yang ditemukan adalah Steatoda bivunctata, Wulfila saltabundus, Cryptachaea porter, Parasteatoda tepidariorum, Enoplognatha ovate, Pholcus phalangoides, Nephila clavipes, Nephila inaurata, Araneus diadematus, 
Philodromus sp, Argiope argentata. Model jaring yang ditemukan adalah heksagonal melingkar, bulat melingkar seperti bunga, bulat meruncing, bulat melingkar berdempetan, menyambung tidak beraturan, berbentuk bintang dan gumpalan asap, bulat melingkar berjarak, heksagonal tidak rapat, garis lurus dengan pintalan benang melingkar dan berbentuk huruf $\mathrm{X}$.

\section{DAFTAR PUSTAKA}

Barrion, AT \& Litsinger. (1995). Riceland Spider Of South And Southeast Asia, International Rice Reserch Institute. Manila: $\mathrm{CAB}$ International.

Gagit, S.M, Setyawati, T.R, Yanti, A.H. (2016) Karakter Morfologi Laba laba yang Ditemukan Di Area Hutan Bukit Tanjung Datok Kabupaten Sambas. Jurnal Probotion, 5(3), 19-27

Koneri R dan Saroyo. (2015). Struktur Komunitas Laba-Laba (Arachnida: Araneae) Di Taman Nasional Bogani Nani Wartabone, Sulawesi Utara. Jurnal Entomologi Indonesia, 12(3), 149-157 ISSN: 1829-7722

Koneri, Roni. (2016). Biodiversitas Laba-laba Di Sulawesi Utara. Bandung: CV. Patra Media Grafindo.

Kurniawan C, Setyawati T R, Yanti A H. Eksplorasi Laba-laba (Araneae) di Hutan Sebelah Darat Desa Lingga Kecamatan Sungai Ambawang. Jurnal Protobiont, 3(2), 218-224

Lia, Mayanda. (2017). Keanekaragaman Spesies dan Struktur Komunitas laba-Laba (Araneae) Pada Tiga Tipe Ekosistem Di Bogor, Jawa Barat. [Tesis]. Sekolah Pasca Sarjana IPB Bogor.

Maramis, R. T. D. (2014). Diversitas Laba-laba (Predator generalis) Pada Tanaman kacang Merah (Vigna angularis) di Kecamatan Tompaso, Kabupaten Minahasa. Jurnal Bioslogos, 4(1), 33-40

Suana I W dan Haryanto H. Keanekaragaman Laba-laba dan Potensinya Sebagai Musuh Alami Hama Tanaman Jambu Mete. Jurnal Entomologi Indonesia, 10(1), 24-30 ISSN: 1892-7722.

Suana I W. (2005). Bioekologi Laba-Laba Pada Bentang Alam Pertanian Di Cianjur: Kasus Daerah Aliran Sungai (DAS) Cianjur, Sub-sub DAS Citarum, Kabupaten Cianjur, Jawa Barat. [Disertasi]. Sekolah Pascasarjana ITB Bogor. 